\title{
The Evaluating Methodology of Municipal Management Performance
}

\author{
Alfiya Ruslanovna Fattakhova ${ }^{1}$, Svetlana Vasilievna Khusainova ${ }^{1} \&$ Gennady Kazimirovich Karnach $^{2}$ \\ ${ }^{1}$ Elabuga Institute (Branch) of Kazan (Volga Region) Federal University \\ ${ }^{2}$ Kazan (Volga Region) Federal University Branch in Naberezhnye Chelny, Suumbike prosp., 10a, Naberegniye \\ Chelni, Russian Federation \\ Correspondence: Alfiya Ruslanovna Fattakhova, Elabuga Institute (Branch) of Kazan (Volga Region) Federal \\ University, Kazanskaya str., 89, Yelabuga, 423604, Russian Federation.
}

Received: November 24, 2014 Accepted: February 5, 2015 Online Published: May 22, 2015

doi:10.5539/ass.v11n14p20 URL: http://dx.doi.org/10.5539/ass.v11n14p20

\begin{abstract}
This article made an attempt to analyze the urban management according to the system approach (Mescon et al., 1988). The examination was fulfilled by the materials of social and economic development of single-industry city Naberezhnye Chelny (Shaykhraziev, 2014), that initially creates complicated conditions for the effective management (Fattakhova, 2011). There are some ways of improving urban management to the individual components of the system such as the operation factors "input", transformation entry-action, the assessment of services as an indicator of the "exit" of the system. The core message is the necessity to apply management sophisticated technologies to the local authority too, as they are used in the operation of enterprises and organizations (Fayolle et al., 1992).
\end{abstract}

Keywords: the municipal management, efficiency, social needs, the system approach, single-industry cities, the population, the customer satisfaction, managerial technologies

\section{Introduction}

The social standard of living is determined by many factors including financial resources, political, geographical, religious, and so forth, determining the social standard of well-being. A municipal management quality defining a quality of life is equally important in framework development. In this paper, consideration the issue of improvement of the effectiveness the municipal management is carried out from the perspective of administrative concept. This approach is due that subjects of management activity represent the owners' interests of their capital and these subjects should meet their fullest. In business a management team usually represents by salaried employees, who know specific goals and objectives. The companies' achieved results are the measure of their fee earnings and foundation for decision making about future career in the company. Drawing a parallel with the local authorities, it is clear that capital owners are a local population and, in fact, they have their votes to determine the direction of their territory and, therefore, they should assess the degree of achievement of objectives. A political system implementing in our country is targeting to this state of things. Nowadays there is an electoral system that allows choosing management subjects, which have a maximum degree of confidence. Elections are carried out periodically, that, actually, forbid "renew" the contract with those who did not reach the goals, not justified confidence. Revisiting the remuneration of municipal employees it is difficult to apply solely market-based approach, involving at least two components: the accountant and part of the bonus (Joseph, 2010). Complexity of the implementation of this mechanism is the need creating an individual approach to each assessed the municipal manager, and in fact the basic conditions for their work initially very different. Territories have different economic base, social potential, demographics, climate and other conditions. In this case, municipal managers are not only the body which carries out the distribution of the funds accruing to the local budget, but also representatives of the government, in whose hands are concentrated the most powerful levers of urban governance in the broadest sense of the term, which implies compulsory foresight risks, their insurance and diversification (Zeldner, 2013). In this regard, multi-criteria evaluation of municipal managers (local authorities) is desirable.

The motive of this study was the economy of Naberezhnye Chelny, the main core of which is focused on urban development enterprise - JSC "KAMAZ". Nowadays, management of Naberezhnye Chelny shows not efficient 
management type. Otherwise it is impossible to explain the state of the industry and urban finance, based on only one manufacturing plant, which is characterized as highly unstable and requiring a standing financial support.

Lack of motivation of local authorities in improving the efficiency of urban management is manifested in study of any local budget sections. One of the major management functions of one of the basic principles is to motivate decision-makers.

\section{Method}

During the operational implementation of different management techniques it is necessary to consider ways to improve the efficiency of municipal managers in the context of management theory and practice. It is important to apply the system (Maiello et al., 2011) approach for built-up social and economic development of cities. The system approach methodology consists of evaluation input factors, its processing by technologies possessing staff, which ultimately leads to the formation the final product, in this case -services.

Let's consider the basic elements analyzing the management municipal corporation. For instance, some factors input may be represented by the following list:

- A legal framework, as a factor constraining or providing additional powers to local authorities (Federal Law, 2003);

- $\quad$ Socio-economic conditions form the basis of development areas funded with employable population and sophistication industry;

- Geographical, climatic and political factors determine the development prospects of the national economy (Zanadvorov \& Zanadvorova, 2003).

Certainly the list could be continued, but the aim is to find ways to solve the problem of uneven development areas. Thus, in accordance with one of the basic principles of Henry Fayol (Fayolle et al., 1992), it is important to provide resource management and after that it allows to claim the achievement certain results.

We should evaluate the area development known as monoindustrial cities. There are lots of distinct sectors in management theory and practice such as risk management, crisis management, involving prevention and negotiation risks and crisis (Geneva, 2010).

Crisis management of enterprises occurring bankruptcy is carried out with the assistance of court-appointed trustees, as an attempt by a third party having a large competencies, to optimize the insolvent company activity (Korotkov, 2008).

Risk management as a preventive measure is also in practice of attracting outside consultants helping quickly identify the symptoms and eliminate the destructive causes.

The leadership movement from one situation to another (Raudeliūnienė \& Meidutè-Kavaliauskienè, 2014) is quite justified management science, supported by practice. It is important to consider monoindustrial cities contrariwise, because they have another financial situation.

According to abovementioned point, it emphasizes that cities have uneven development, including the reason of non-equivalence of output baseline conditions (ie, input parameters), and it must be taken into account when we assess the municipal managers performance.

Administrative technologies allow to obtain a result from less high quality raw product to more high set level of quality. For instance, some cities have been able to stop being a single industry and evolved into self-contained urban areas. It indicates that the municipal managers have a managerial talent.

The appearance of single-industry cities carried out on the basis of the implementation of national policy, and it did not has a long-term development plans. Primary single-industry cities were appeared in the Industrial age of Peter I. The cloth and iron manufacture required a large number of hands. State-owned, serfs, military and convict workers were involved in factories.

Initially industrial plants were formed without a sufficient level of culture and a science-driven opportunity. Later some of them outgrow into a major industrial centers (Chelyabinsk, Tula, Chrysostom), and remainders are still represent a single-industry cities (Irbit, Asha). Thus, cities were emerged and developed, focusing in a large industrial facilities range (Fattakhova, 2011, p. 10).

For example, at the level of municipal management, in terms of management of municipal property, it is advisable to engage external managers on a competitive basis. A professional approach concept to systems management technology (serveyinga) is widespread in the world. The feasibility of a proceeding of external managers of municipal property is caused by: 
- officers of a town hall machinery are far from market foundations to establish a leasehold ground rent and capital facilities, so competitive managers are able to more effectively manage municipal property;

- local authorities will have powers to select one of several applicants, as well as the right to exercise control functions to identify the effectiveness and scheduling of cooperation with external managers.

The implementation of audit function is advisable to consolidate under the local level in this field (Fattakhova, 2012 , p. 133). Currently, there is a regulatory framework that allows to evaluate the municipal management activities (Decree of the President of Russia, 2008). In accordance with the Decree of President the assessment of bodies of local government in urban districts and municipal districts is carried out on 13 core indicators and 27 additional. The list is very comprehensive and it allows to identify trends in the socio-economic development of a particular locality. It includes:

1. The number of small and medium business per capita.

2. A rake off average number of employees (without external part-timer) of small and medium business in average number of employees (without external part-timer) of all businesses and organizations.

3. A rank off length of public roads which do not meet the regulatory requirements in the total length of public roads.

4. A share of population living in towns that do not have a regular bus service and (or) a railway communication with the administrative center, in the total population of the urban district.

5. A rank off land plot area that is a taxable item in the total area of the urban district (municipal district).

6 A rake off children at the age one to six years who are registered for the determination to pre-school educational institution, in the total number of children aged one to six years.

7. A rake off the municipal educational institutions graduates who have passed the unified state exam in Russian language and Math, in the total number of the municipal educational institutions graduates, who passed the unified state examination.

8. A rake off overall area per person.

9. A rake off municipal utilities realizing manufacture of goods and provision of services for water, heat, gas, electricity, sanitation, sewage treatment, and disposal (dumping) of municipal solid waste.

10. A rake off apartment blocks located on land parcel. A cadastral registration was done of them.

11. A specific quantity of the consumption of energy (electricity and heat energy, water, natural gas) in apartment blocks (based on 1 square. meter for one person).

12. A specific quantity of the consumption of energy (electricity and heat energy, water, natural gas) municipal budgetary institutions (based on 1 square. meter for one person).

13. People satisfaction of self-governing authorities activity in urban district (percentage of respondents).

These figures are a result of policies by local authorities and serve as a criteria for decision-making by higher-level authorities about amounts of financial investments from higher levels of budget system. The basic idea of carrying a monitoring is to encourage the best one.

According to the management methodology (Cohen \& Amorós, 2014), it is clear that motivation as a way of encouraging productive and more productive activities is not always necessary because there are situations when the use of incentives, suggesting effects due to external stimuli are justified. Thus, we consider include not only the fact of evaluating progress of socio-economic development, but also a formulation of specific values of individual indicators, as a way to stimulate (Ministry of Economic Development Russian Federation, 2014).

The method of estimating the local authorities' efficiency, in which there is the indicator "People satisfaction of local authorities' activity of urban district (municipal district) (percentage of respondents)," a summary evaluation is formed by the following criteria:

1. People satisfaction with public transport services in the municipality (percent of respondents).

2. People satisfaction with the quality of public roads in the municipality (percent of respondents).

3. People satisfaction with housing and public utility services: the level of organization heating (fuel supply), water (drainage), electricity, gas (percent of respondents).

These criterias are certainly important in determining the level of the territory development, however, in our opinion, they are not enough exhaustive to evaluate the effectiveness of the municipal authorities. 
According to the survey (Fattakhova, 2012) one of the questions concerning social needs was: "For what purpose it is necessary to direct the resources of the municipal budget at the beginning?" Of the proposed answers were chosen:

- To increase salaries, pensions and allowances - in most cases (57.3\% of responses);

- to improve the medical aid degree $(56.4 \%)$

- to development of production and the creation $\mathrm{f}$ new jobs (42.3\%).

Therefore, the list of estimated parameters should include some critical issues. For example, problems concerning lack of creating work opportunities seems to be marked by a separate indicator "number of small and medium businesses". In considering the reported data (FTS, 2014) we can see a positive trend. It must be said as in the whole of the Russian Federation. However, 932.8 thousand of self-employed entrepreneur ceased activities in 2013. It is 32.9\% more than in 2012 (702.1 thousand of self-employed entrepreneurs).

Based on above as an indicator of development of the area and performance evaluation of local government seems appropriate to assess not only a number of small and medium businesses, but their share of operating more than one year.

The number of opened businesses and registered enterprises is not as revealing as their number is steadily functioning. Because federal law creates the framework conditions of business creation, and local authorities create specific conditions for their operation on the ground, so the number of stable working for small and medium businesses will evaluate the activity of self-governing authorities for the development city facilities (districts, municipalities).

A striking indicator of social standard of living is not only the magnitude of the average monthly nominal wages, but also a spending patterns (some average "bundle of goods"). Assessment of personal income from a qualitative standpoint - namely, a spending patterns, will determine the level of life quality. In this regard, we consider include not only information of wages, but a spending pattern in evaluating the performance of local government. It should not forget about the serious income differentiation, exacerbated by the division to "rich" and "poor" (Ministry of Economic Development Russian Federation, 2014).

\section{Results}

During survey there were some questions allowing to assess the municipal managers activities by three criteria indicated in the aforementioned Decree of the President (Fattakhova, 2012).

Citizens emphasized problems concerning public transport. Some of them are:

1. A poor technical condition (52\% of responses). Unresolved situation of funding of travel privileges deprives owners of public transport part of revenues, which reduces not only the amount of working capital and does not allow to invest in the renewal of the bus fleet.

2. A deterioration of transport and the high cost of travel are almost equally cause discontent citizens (47\%). This fact can be explained only by the lack of income per capita of those who use public transport.

3 . In the third flight ( $27 \%$ response) - is insufficient quantity of vehicles. In view of the rapid growth of the city building, increasing residential development, transport infrastructure is formed with some delay and residents of new neighborhoods experiencing restrictions due to insufficient public transport vehicles.

One of the most "eloquent" certificates to ensure a quality of life is a condition of the roads in a locality. Respondents opinion were divided as follows: a decentish condition of the roads $(49.8 \%)$, much less - $(32.3 \%)$ assessed as poor and very poor, and only $14.4 \%$ of respondents say that roads are good (FTS, 2014).

The most pressing problems of residents of Naberezhnye Chelny were classified as follows: in the first place in order of importance (47.8\%), is environment, the second (43\%) - is alcoholism and drug addiction, as well as the work of medical institutions (42.6\%), in the third place $(41.7 \%)$ - is the work of housing and utilities infrastructure.

\section{Discussion}

During the survey in 2012 (Shaykhraziev 2014) some inconsistency revealed. Thus, official data have concluded that $83.7 \%$ of the population are satisfied with the activities of local governments. According to the results of an independent survey in 2011, people satisfaction of a various sphere of life in the city of Naberezhnye Chelny are different. In this case, a received results indicate the need for a significant concentration of efforts in some areas especially, for example, at least $30 \%$ of the population call a variety of problems in public transport, $50 \%$ did not 
recognize a quality of roads, more than $40 \%$ of the population is not satisfied with the operation of the system Housing.

Activities to attract investment in fixed assets includes as the object of evaluation of local government performance. There is no doubt that this aspect of regional and local policies is a strategic importance, but it is necessary to assess the implementation of investment social projects, which allows realizing the mechanism of public-private partnerships. It should be noted that this implementation is more difficult due to a lack of activity of private investment.

From the perspective of private investor motivational incentives can be:

- the existence of stable and efficient source of core funding on behalf of the state;

- reduction time of "bureaucratic procedures" in solving managerial and organizational issues;

- guarantee payment of financial risks;

- improving the company's image, as the subject market-driven economy, collaborating with the state;

- provision of benefits to the rents, taxes, lending;

- the ability to operate a monopoly in a particular area.

We can distinguish general and particular risks in different sectors and scopes of activities. But, of course, a decisive factor is the guarantee of return on investment and a stable market. Successful mechanism for ensuring availability of supply is the system of public procurement, but the practice of its functioning indicates the presence of barriers to potential participants, primarily financial. Practice of successful public-private partnership shows that the state's participation in such projects significantly increases the attractiveness for private investment capital. This factor is a recurrence of financial investments and a significant risk minimization.

The second aspect of this Union will be represented by public authorities, as a rule, the representatives of the municipalities. It is assumed that the majority of municipal managers do not experience any influence of motivational and / or stimulating leverage in determining the most effective way to manage state property. Therefore, the establishment of partnerships with the private sector is not always a promising alternative to competitive strategic management of public or municipal property.

Therefore, one of evaluated indicators should be not only the index of amount of investment, but also a qualitative parameter for assessing the degree of diversification of the economy.

The problems of lack of substitute tax field instead of the main enterprise of JSC "KAMAZ" close to most citizens, because the enterprise performance directly or indirectly affects all spheres of life of the city.

In such cases, one of the potential sources of revenue performance budgeting should be a tourist activity, which is not a capital-intensive, but it has a multiplier effect (Resolution of the Government of the Russian Federation, 2011).

Tourism activity in the Russian Federation is one of the priority economy sectors (Federal Law, 2011)). In this case, tourism activity is tour operator activities and travel agency activities and other travel activities. This article focuses on some aspects of tourism activities that contribute a socio-economic development of local areas. These types of tourist activities include domestic and inbound tourism (Kabushkin, 1999). Prospects for domestic tourism less distant compared with inbound tourism to areas that are not central areas in which focused on business and industrial infrastructure of the country. For this reason, for small and monoindustrial cities, cities that do not have extensive social infrastructure, one of the main potential sources of replenishment in budget revenues are revenues from domestic tourism.

The question arises as to whether financing this type of projects in the cities with deficit-ridden budget. Therefore the role of the state is indispensable. It should be noted about the action of the Federal Target Program "Development of domestic tourism in the Russian Federation (2011-2018 years)", adopted by Resolution of the Government of the Russian Federation dated August 2, 2011 \# 644. In this program, considerable attention is given to the development of tourism in the Russian Federation: "One of the main transition to innovative socially-oriented type of economic development is to create conditions for improving the quality of life of citizens of the Russian Federation, including through the development of infrastructure, recreation and tourism, as well as ensuring the quality, accessibility and competitiveness of tourist services in the Russian Federation". Therefore, tourism, especially domestic, is a factor of development of the economy and consolidation competitive position in the international tourism market. 
In addition, domestic tourism is one of the ways of improvement of the nation by creating the conditions for a healthy lifestyle.

The mechanism of a multiplier effect on the development domestic tourism is quite transparent: creating more jobs, increasing employment, increases the welfare of the population. Related areas of activity, such as accommodation facilities, transportation, communications, trade, production of souvenirs and other products, food, agriculture, construction and others are involved.

Naberezhnye Chelny has tourism and recreational potential. There are natural and recreational resources (health centers, the National Park "Lower Kama") and objects of national cultural and historical heritage.

The extensive range of tourist and recreational resources allows to develop all types of tourism, including recreational, cultural, educational, business, active, health and eco-tourism, sporting and recreational fishing, rural tourism and etc.

\section{Inference}

Domestic tourism has significant opportunities and development prospects, but the local budget needs the initial investment. In this case there are two ways to search the financial sources: the first - a state, the second - a private. The first method is obviously limited due to a scarcity of most local budgets. The second method has a significant backlog, but we need a mechanism to minimize the risk and insurance against loss of investment by private investors.

Of course, not all of these problems can be solved within the competence of municipal managers and they require the involvement of higher authorities. However, a participation in the formation and development prospects territories through the initiative proposals should form the terms of reference and responsibilities of local authorities. So the range of questions to assess public satisfaction with local authorities' activities should be expanded and an expanded list should evaluate their work. In addition, for certain territories it is necessary to define minimum thresholds compulsory achieve certain indicators of socio-economic development.

\section{References}

Cohen, B., Amorós, J. (2014). Municipal demand-side policy tools and the strategic management of technology life cycles. Technovation, In Press, Corrected Proof. http://dx.doi.org/10.1016/j.technovation.2014.07.001

Decree of the President of Russia. (2008). Respecting the evaluation of the effectiveness of local governments in urban and municipal districts' from April 28, 2008\#607. Retrieved September 10, 2014, from http://http://www.consultant.ru

Fattakhova, A. R. (2011). Factors and conditions of monocities budgets form (for example, the Naberezhnye Chelny city). Naberezhnye Chelny's branch of the federal government's budget educational institution of higher prof. education "Nizhny Novgorod State Linguistic University. N.A. Dobrolyubov" (branch VPO "NGLU").

Fattakhova, A. R. (2012). Assessment of financing social needs of different respondents groups. Problems of Economics and Law, 10, 131-136.

Fayolle, A., Emerson, G., Taylor, F., \& Ford, G. (1992). Management - the science and art. Moscow: The Republic.

Federal Law. (2003). "On General Principles of Local Self-Government in the Russian Federation" of October 6, 2003 N 131-FZ. Retrieved September, 29, 2014, from http:// www.consultant.ru.

Federal Law. (2011). "On the Principles of tourist activities in the Russian Federation" from November 24, 1996 \# 132-FZ (as amended. from 01.07.2011 \# 169-FZ). Retrieved September 10, 2014, from http://www.consultant.ru

FTS. (2014). The number of SP in 2013, fell sharply. Retrieved September 19, 2014, from http://www.vestifinance.ru/articles/38459

Geneva. (2010). World Economic Forum Global Risk Report 2010.

Joseph, S. (2010). FREEFALL: Free Markets and Sinking of the Global Economy. Allen Lane.

Kabushkin, N. I. (1999). Tourism Management: Proc. allowance. Mn.: BGEU.

Korotkov, E. (2008). Crisis Management. M.: Infra-M.

Maiello, A., Battaglia, M., Daddi, T., \& Frey, M. (2011). A tale of four towns. Futures Urban sustainability and knowledge: Theoretical heterogeneity and the need of a transdisciplinary framework, 43, 1164-1171. 
Mescon, M., Michael, H., Michael, A., \& Khedouri, F. (1988). Management. New York: Harper \& Row.

Ministry of Economic Development Russian Federation. (2014). Retrieved September 10, 2014, from http://www.economy.gov.ru

Raudeliūnienè, J., \& Meidutè-Kavaliauskienė, I. (2014). Analysis of Factors Motivating Human Resources in Public Sector. Procedia - Social and Behavioral Sciences, 110, 719-722. http://dx.doi.org/10.1016/j.sbspro. 2013.12.916

Resolution of the Government of the Russian Federation. (2011). Federal Target Program "Development of domestic tourism in the Russian Federation (2011-2018)" of 02.08.2011, \# 644. Retrieved September 28, 2014, from http:// www.consultant.ru

Shaykhraziev, V. G. (2014). Assess indicators the effectiveness of local government municipal entity of Naberezhnye Chelny Republic of Tatarstan. Retrieved July 30, 2014, from http://www.nabchelny.ru/ company.

Zanadvorov, V. S., \& Zanadvorova, A. V. (2003). Economy of the city. Introductory Course: Textbook. M.: ICC "Akademkniga".

Zeldner, A. G. (2013). Destructive tendencies and design capabilities to overcome them in the economic system of Russia. A G Zeldner. - M .: CJSC "Publishing House" Economics".

\section{Copyrights}

Copyright for this article is retained by the author(s), with first publication rights granted to the journal.

This is an open-access article distributed under the terms and conditions of the Creative Commons Attribution license (http://creativecommons.org/licenses/by/3.0/). 